\title{
Microstructure and Fracture Morphology of Thermally Sprayed Refractory Metals and Ceramics
}

\author{
O. Kováríik ${ }^{1, a}$ and J. Siegl ${ }^{1}$
}

${ }^{1}$ Czech Technical University in Prague, Faculty of Nuclear Sciences and Physical Engineering, Department of Materials, Prague, Czech Republic

a kovon@seznam.cz

The microstructural characteristics such as porosity, splat morphology and grain size of thermally sprayed coatings made of both ceramic and refractory metals are investigated. $\mathrm{Al}_{2} \mathrm{O}_{3}$ and $\mathrm{Cr}_{2} \mathrm{O}_{3}$ coatings represent ceramic materials while pure $W$ and Mo coatings represent the refractory metals. The used deposition technology (RF-plasma, gas stabilized or water stabilized DC plasma) was found to influence the coatings microstructure to a great extent by providing different particle impact velocities and temperatures. At the same time the substrate temperature plays an important role as is shown for refractory metal coatings deposited at different substrate temperatures. Generally, all investigated coatings contained intrasplat cracks, intersplat pores and voids, individual splats of different degree of deformation and different degree of intersplat sintering, crystal grains formed inside individual splats or extending through many of them. It is shown that the size and abundance of the above-mentioned microstructural features predetermine the fracture morphology of the coating as well as mechanical properties.

Keywords: thermal spraying, refractory materials, microstructure, fractography, elastic modulus.

Introduction. The increasing demands for sophisticated construction parts with increased corrosion and heat resistance lead to the increased use of protective coatings. Refractory materials fulfill the demands for corrosion, thermal, wear and fatigue resistance and, when applied as coatings, help to preserve the low weight and mechanical properties of the substrate material. A great advantage of protective coatings is the possibility to renew the part by replacing any worn coating.

We discuss deposit properties of several thermally sprayed coatings of engineering importance sprayed by three different techniques. The spray technology and process parameters used are selected for each feedstock in order to provide favorable particle state for the deposition based on previous experiments [1-3].

Experimental. Refractory ceramics $\mathrm{Al}_{2} \mathrm{O}_{3}$ and $\mathrm{Cr}_{2} \mathrm{O}_{3}$ were deposited on flat $4 \mathrm{~mm}$ thick mild steel substrates by WSP ${ }^{\mathbb{B}}$ PAL 160 water stabilized plasma torch at IPP, CAS, Czech Republic. Tungsten deposits were prepared on thick stainless steel substrates by Tekna PL-50 RF-ICP torch in an inert atmosphere at CREPE Sherbrooke, Quebec, Canada. Molybdenum coatings were prepared on flat $4 \mathrm{~mm}$ thick mild steel substrates by APS DC plasma torch Metco 3MB at CTSR, Stony Brooke, NY, USA. Spray conditions are listed in Table 1. All substrates were grit-blasted before spraying.

The in-flight particle properties were measured using DPV-2000 instrument. The elastic modulus of the Mo coatings was measured by four-point bending tests as described in [4]. Moduli of other deposits were estimated from resonance frequency of the coating beam. The total deposit porosity (open and closed) was estimated by weighting a sample of the known volume using a precision scale.

Metallographic specimens for structure observations were prepared by electrolytic polishing and etching. The splat thickness was measured by image analysis on a polished/etched cross-section and the value is an average of approximately 200 measurements. 


\begin{tabular}{|c|c|c|c|c|c|c|c|c|c|c|}
\hline \multicolumn{11}{|c|}{ T a b 1 e 1} \\
\hline Feedstock & $\begin{array}{c}\text { Spray } \\
\text { techno- } \\
\text { logy }\end{array}$ & $\begin{array}{l}T_{s}, \\
{ }^{\circ} \mathrm{C}\end{array}$ & $\begin{array}{c}q_{c} \\
\text { slpm* }\end{array}$ & $\begin{array}{c}q_{p} \\
\text { slpm }\end{array}$ & $\begin{array}{c}q_{s} \\
\text { slpm }\end{array}$ & $\begin{array}{l}\text { feed } \\
\text { rate, } \\
\mathrm{g} / \mathrm{mm}\end{array}$ & $\begin{array}{c}P \\
\mathrm{~kW}\end{array}$ & $\begin{array}{l}T_{p}, \\
{ }^{\circ} \mathrm{C}\end{array}$ & $\begin{array}{l}v_{p}= \\
{ }^{\circ} \mathrm{C}\end{array}$ & $\begin{array}{c}d_{\text {mean }} \\
\mu \mathrm{m}\end{array}$ \\
\hline W & $\mathrm{RF} / \mathrm{ICP}$ & 560 & $6.3(\mathrm{He})$ & 30 (Ar) & $\begin{array}{c}100(\mathrm{Ar})+ \\
15\left(\mathrm{H}_{2}\right)\end{array}$ & 40 & 80 & $4120 * *$ & $40^{* *}$ & $61 * *$ \\
\hline W & $\mathrm{RF} / \mathrm{ICP}$ & 430 & $6.3(\mathrm{He})$ & 30 (Ar) & $\begin{array}{c}100(\mathrm{Ar})+ \\
15\left(\mathrm{H}_{2}\right)\end{array}$ & 40 & 80 & $4120 * *$ & $40^{* *}$ & $61 * *$ \\
\hline W & RF/ICP & 285 & $6.3(\mathrm{He})$ & $30(\mathrm{Ar})$ & $\begin{array}{c}100(\mathrm{Ar})+ \\
15\left(\mathrm{H}_{2}\right)\end{array}$ & 40 & 80 & $4120 * *$ & $40 * *$ & $61 *$ \\
\hline Mo & GSP & 250 & $6(\mathrm{Ar})$ & 40 (Ar) & $10\left(\mathrm{H}_{2}\right)$ & 60 & 33 & 3100 & 132 & 65 \\
\hline Mo & GSP & 120 & $6(\mathrm{Ar})$ & $40(\mathrm{Ar})$ & $10\left(\mathrm{H}_{2}\right)$ & 60 & 33 & 3100 & 132 & 65 \\
\hline $\mathrm{Al}_{2} \mathrm{O}_{3}$ & WSP & 120 & $\mathrm{~N}_{2}$ & - & - & 433 & 160 & - & - & 50 \\
\hline $\mathrm{Cr}_{2} \mathrm{O}_{3}$ & WSP & 90 & $\mathrm{~N}_{2}$ & - & - & 530 & 160 & - & - & 50 \\
\hline
\end{tabular}

Notes: * standard liters per minute; ** volumetric median; GSP = gas stabilized plasma; WSP = water stabilized plasma; $T_{s}$ is substrate temperature; $q_{c}$ is carrier gas flowrate; $q_{p}$ is primary (plasma) gas flowrate; $q_{s}$ is secondary (sheath) gas flowrate; $P$ is torch power; $T_{p}$ is mean particle temperature; $v_{p}$ is mean particle velocity; $d_{\text {mean }}$ is mean particle diameter.

Results and Discussion. The measured in-flight temperature data ensure proper melting of the feedstock powders and limited feedstock evaporation (see Table 1). The impact velocity of the Mo particles was much higher than that of the $\mathrm{W}$ particles (see Table 1) resulting in thinner splats (Table 2). Elastic moduli (Table 2) of the coating ranges from 4 to $44 \%$ of bulk material modulus, both extreme cases were obtained for the W deposits sprayed under the same conditions, but different $T_{s}$. The deposit porosity $\phi$ (see Table 2) ranges from $2 \%$ to $33 \%$ with the lowest porosity achieved for $\mathrm{W}$ and highest for $\mathrm{Al}_{2} \mathrm{O}_{3}$.

$\mathrm{T}$ a b 1 e 2

Deposit Properties

\begin{tabular}{|c|c|c|c|c|c|c|c|c|}
\hline Feedstock & $\begin{array}{c}\text { Spray } \\
\text { technology }\end{array}$ & $\begin{array}{c}T_{s}, \\
{ }^{\circ} \mathrm{C}\end{array}$ & $\begin{array}{c}E_{z} \\
\mathrm{GPa}\end{array}$ & $\begin{array}{c}E_{\text {bulk }} \\
\mathrm{GPa}\end{array}$ & $\frac{E}{E_{\text {bulk }}}$ & $\phi$ & $\begin{array}{c}h_{\text {coating }}, \\
\text { mm }\end{array}$ & $\begin{array}{c}h_{\text {splat }}, \\
\mathrm{mm}\end{array}$ \\
\hline $\mathrm{W}$ & RF/ICP & 560 & 182 & 411 & 0.44 & 0.09 & 0.60 & 6.30 \\
$\mathrm{~W}$ & RF/ICP & 430 & 179 & 411 & 0.44 & 0.02 & 0.42 & 6.30 \\
$W$ & RF/ICP & 285 & 17 & 411 & 0.04 & 0.06 & 0.46 & 7.00 \\
$\mathrm{Mo}$ & GSP & 120 & 45 & 329 & 0.14 & 0.15 & 0.28 & 4.60 \\
$\mathrm{Mo}$ & GSP & 250 & 43 & 329 & 0.13 & 0.27 & 0.31 & 4.50 \\
$\mathrm{Al}_{2} \mathrm{O}_{3}$ & WSP & 120 & 48 & 345 & 0.14 & 0.33 & 0.35 & 7.00 \\
$\mathrm{Cr}_{2} \mathrm{O}_{3}$ & WSP & 90 & 43 & 350 & 0.12 & 0.30 & 0.44 & 7.50 \\
\hline
\end{tabular}

The results obtained clearly show the importance of the substrate temperature on the deposit properties. The micrographs in Fig. 1 reveal two types of the deposit structure. For the Mo deposits and the tungsten deposit at $290^{\circ} \mathrm{C}$, the intersplat porosity contributes significantly to the total porosity. On the other hand, the $\mathrm{W}$ deposits at $430^{\circ} \mathrm{C}$ (Fig. 1) and $560^{\circ} \mathrm{C}$ (not included on Fig. 1) show intersplat boundaries but only a limited number of intersplat pores. In the case of W, the steep increase of elastic modulus between 290 and $430^{\circ} \mathrm{C}$ was detected (Fig. 2), suggesting the transition temperature (change from splash- 
splats to disc-splats, [5]) of $\mathrm{W}$ on $\mathrm{W}$ system is situated in that range. No similar change was detected for Mo, probably due to a low substrate temperature. The transition temperature of $\mathrm{Mo}$ on steel is reported in the range of $300-400^{\circ} \mathrm{C}$ in [6] and around $300^{\circ} \mathrm{C}$ in [7].

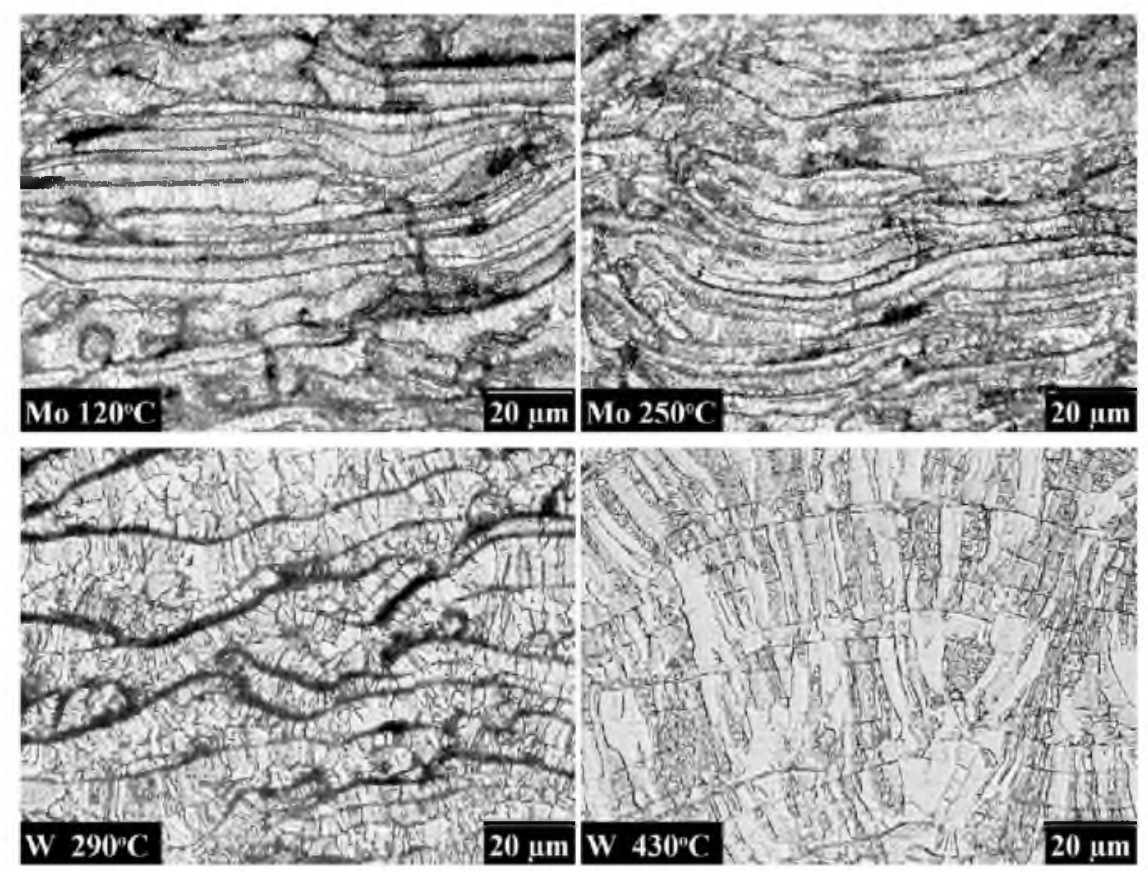

Fig. 1. The influence of substrate temperature on coating microstructure for $\mathrm{W}$ and Mo coatings.

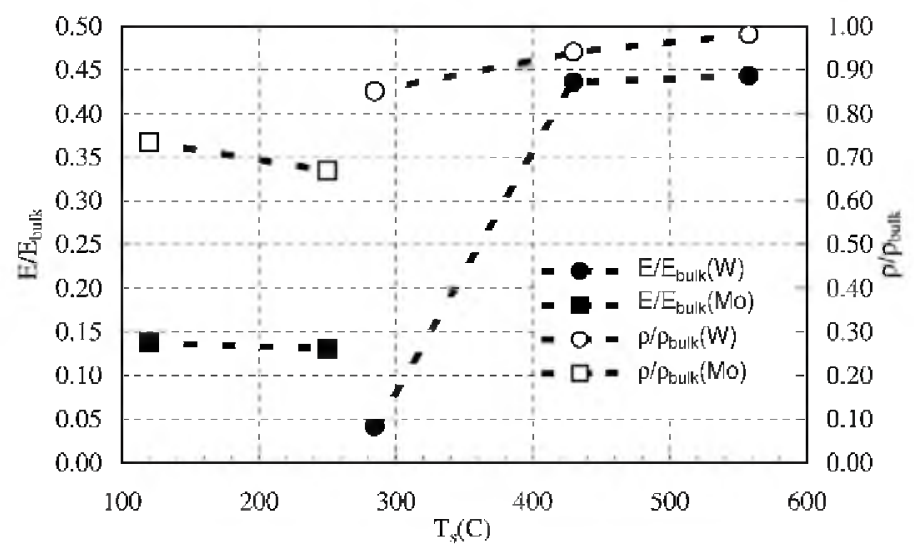

Fig. 2. The elastic modulus and relative density of Mo and $\mathrm{W}$ deposits vs. the substrate temperature

The metallographic samples of ceramic deposits prepared by ion milling showed an extensive porosity network formed by intersplat pores and intrasplat cracks. In order to visualize the crystal structure, the specimens were ruptured on a tensile machine and the coating fracture was observed (Fig. 3). The micrographs show columnar grain structure of the splats and dendritic structure of spherical particles (that impacted in solid state). The transition temperature for ceramic materials is supposed to be lower than that for metals (in the range between 100 and $200^{\circ} \mathrm{C}$, [8]). Thus, it is possible that ceramic coatings were deposited above the transition temperature, as suggested by the splat morphology. 


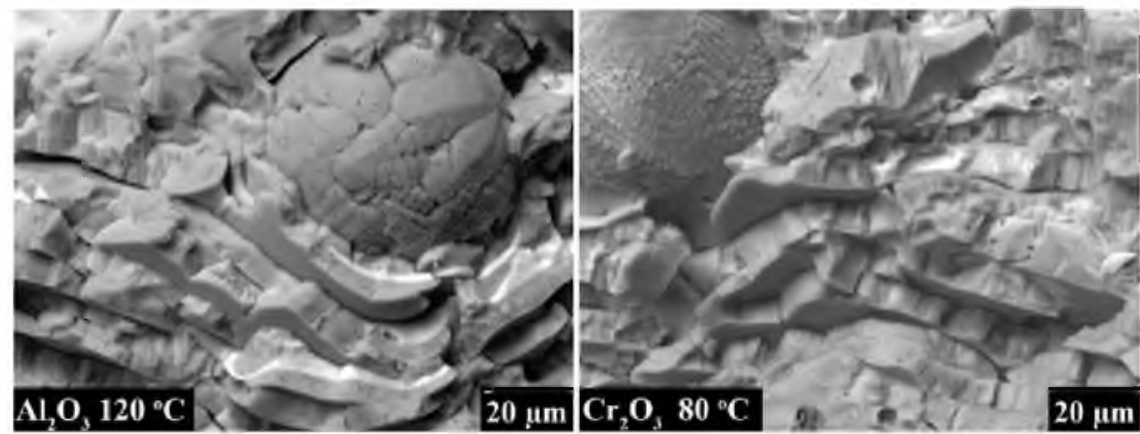

Fig. 3. The fracture surfaces of ceramics deposits showing lamellar structure of the deposit and spherical particles.

Conclusions. The coating structure of the deposits investigated consists of individual splats and a porosity network formed by intersplat pores and intrasplat cracks. More intrasplat cracks occurred in ceramic deposits due to its brittle nature. Dense W deposits with a high modulus were obtained at an elevated substrate temperature.

Acknowledgment. This research has been supported by the Czech Science Foundation through Grant No. 106/05/0483 "Influence of Microstructure on Mechanical Properties of Thermally Sprayed Materials."

1. O. Kováríik, S. Xue, X. Fan, and M. Boulos, "RF plasma deposition of refractory metals: Case study for tungsten," in: B. R. Marple, M. M. Hyland, Y. C. Lau, et al. (Eds.), Building on 100 Years of Success, Proc. of the 2006 International Thermal Spray Conference (Seattle, USA), ASM International (2006), pp. 215-218.

2. J. Matejicek, S. Sampath, D. Gilmore, and R. Neiser, Acta Mater., 51, No. 3, 873-885 (2002)

3. J. Dubský, B. Kolman, and M. Vyš̃ohlíd, in: E. Lugscheider and P. A. Kammer (Eds.), Proc. of the United Thermal Spray Conference (UTSC 99), Verlag fbr Schweien und Verwande Veflahren, D.V.S-Verlag (1999), pp. 659-663.

4. O. Kovárík, J. Nohava, J. Siegl, and P. Chraska, J. Therm. Spray Technol., 14, No. 2, 231-238 (2005).

5. P. Fauchais, M. Fukumoto, A. Vardelle, and M. Vardelle, I. Therm. Spray Technol., 13, No. 3, 337-360 (2004)

6. X. Jiang, J. Matejicek, and S. Sampath, Mat. Sci. Eng. A, 272, No. 1, 189-198 (1999).

7. X. Jiang and S. Sampath, Mat. Sci. Eng. A, 304-306, 144-150 (2001).

8. L. Bianchi, F. Blein, P. Lucchese, et al., in: C. Berndt and S. Sampath (Eds.), Thermal Spray Industrial Applications, ASM International, Metals Park, Ohio (1994), p. 569.

Received 28. 06. 2007 